DOI: 10.32370/IA_2021_12_24

\title{
Methodological Fundamentals for Forming Art Values of Students-Musicians in Arts and Educational Activities
}

\author{
Chen Liang (China) \\ Postgraduate Student of Faculty of Arts named after Anatoliy Avdiyevskiy, \\ Drahomanov National Pedagogical University \\ ORCID: https://orcid.org/0000-0002-2630-6433
}

\begin{abstract}
The article is devoted to the problem of value formation of a future music teacher in the process of professional training. Art education is considered as a component of training that accumulates performing, musical, methodological directions. The artistic education for Music teachers determines the poly-artistic vector of professional training, which includes understanding music and other arts. The success of artistic education is ensured by the subjectivity of a future teacher-musician who accepts such activities as a universal professional value.

The hierarchy of pedagogical conditions of effective arts and educational activities is substantiated. The initial positions for substantiation of methodological fundamentals of arts and educational activities of the future Music teacher are specified, namely teacher's focus on self-development and on values of other people. The groups of methods relate to motivation for the complex of musical activity, poly-artistic development, thesaurus in the field of various arts. The core of the methodological fundamentals is personal artistic communication with art as well as interpersonal artistic communication. The need for the functioning of a specific arts and educational environment is substantiated in order to provide artistic communication,

The functional connection of pedagogical conditions and methods of formation of artistic values of students-musicians in arts and educational activities as subjects of environmental art education is explained. The prospects of research of the problem caused by actualization of processes of virtual communication, risks of minimizing of interpersonal art communication are defined.
\end{abstract}

Key words: students-musicians, arts and educational activities, artistic values, artistic communication, environmental art education.

Актуальність дослідження. Формування культури суспільства значною мірою визначається готовністю його членів позиціонувати себе як людину культури і бути суб'єктом культурно-освітніх процесів. Перед педагогом будь-якого фаху постають виклики просвітництва, активність якого, як засвідчують опитування студентів мистецьких факультетів, останнім часом знизилась разом із зниженням уваги до цього чинника професійної підготовки. Натомість просвітництво, як складник цієї підготовки майбутніх викладачів мистецтва акумулює процеси художнього пізнання, активізує його діяльнісні аспекти, емоційну сферу, а отже й емоційний інтелект, здатність художньої емпатії та рефлексії, критичність мислення в дискусійному інформаційному просторі, зрештою впливає на систему цінностей. Аксіоматично, що поза сформованими цінностями, педагогічна, і загалом творча діяльність музиканта, зводиться нанівець. 
Тому мета cmammi - окреслити методичні засади, за дотриманням яких просвітництво оптимально впливатиме на художні цінності майбутніх педагогівмузикантів.

Виклад основного матеріалу. Спираючись на теоретичний аналіз дефініцій «цінності особистості» (Г.Ф. Гегель, І.Кант, А. Маслоу, К. Роджерс, В. Франкл, концепції Шварца-Білскі, сучасні вчені - В. Андрющенк, ..Бех, І. Зязюн, О. Комаровська, Л.Левчук, Д.Леонтьєв, А.Ручк та ін.), «просвітництво» (історіографічні дослідження, діяльність Інституту Конфуція та ін.) та «музично-педагогічна діяльність» (С. Горбенко, А. Козир, Лю Бінцян, Т.Рейзекінд, Ся Гаоян, В. Прокопчук, Фань Чженьсюань, О. Щолокова, В. Черкасов, К. Шамаєва, В.Шульгіна та ін.), автор у низці публікацій виклав своє бачення художньо-ціннісної сфери педагога-музиканта та ціннісно-педагогічного потенціалу мистецько-просвітницької діяльності $[11 ; 12]$.

Так, аксіоматично, що будь-яке уявлення людини про об’єктивну цінність перетворюється на рушій її особистісного зростання лише в разі, якщо людина культивує власну суб’єктність у процесі становлення. На механізми цього вказує В. Татенко: чим більше людина усвідомлює себе суб'єктом, тим краще вона усвідомлює навколишні процеси і події, а головне - тим глибше вона пізнає саму себе [8, с. 7]. Це пов’язано із тим, що, як стверджує К. Роджерс, цінності (вчений пише про універсальні цінності) не існують самі по собі як абстрактні величини, а «містяться» в самій людині, невід'ємно від іiї внутрішнього світу; тому їх неможливо просто «надати» людині; вона може лише привласнити їх сама [9]. Така привласнена цінність як смислова універсалія (за В. Франклом [10, с. 12]) і дає людині можливість сформувати смисложиттєву позицію, від якої вона невзмозі відступити. Відповідно для кожної людини цінність є одночасно і

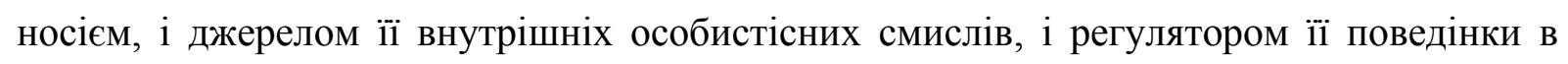
повсякденні та професії [5].

Для майбутнього вчителя музики в силу професійних вимог однією 3 універсальних цінностей є музичне мистецтво і музична/ музично-педагогічна творчість, оскільки він є носієм особистісних музичних цінностей, що багато в чому збігаються 3 професійно-педагогічними. В музичній діяльності такі цінності i формуються, i розкриваються, і впливають на самоформування в процесі виконавства, музикознавчого пошуку, викладання. У будь-якому разі фахова підготовка передбачає розширення меж 
пізнання лише музики, диктує свого роду «ціннісну поліхудожність» [19]. Тим паче, що і в Китаї, і в Україні тенденції освітніх процесів такі, що вчитель музики одночасно має бути готовим виконувати більш широкі завдання: навчати учнів різних видів мистецтва. Відтак складником професійної діяльності, який акумулює різні складники майбутньої професійно-педагогічної діяльності студента-музиканта мистецького-педагогічного закладу освіти, є мистецькке просвітнищтвво.

У визначенні просвітництва в широкому розумінні спираємось на офіційні джерела, а саме на чинний донині міжнародний Модельний закон [6]. Відповідно до цього документа просвітницька діяльність тлумачиться як така, що формально здійснюється поза офіційним здобуттям професії і $є$ сукупністю інформаційно-освітніх заходів із цілеспрямованого поширення знань у суспільстві; така діяльність складається із сукупності «заходів», які виступають їі змістовими і організаційними одиницями, що послідовно реалізують поширення знань. Приймаючи це тлумачення в цілому, все ж підкреслимо: для музиканта просвітницька діяльність є професійною за своєю суттю, а отже має здобуватись не «поза», а у контексті фахової підготовки, що охоплює освоєння музичного мистецтва та пізнання інших мистецтв, котрі посилюють різноаспектне занурення в музику. Саме в цьому сконцентровано ціннісний потенціал мистецького просвітництва для майбутнього вчителя музики.

Отже, визначаємо вихідні позииії для обгрунтування методичних засад ціннісного становлення музиканта-педагога, зокрема спираємось на той беззаперечний факт, що цінності зумовлюють і визначають вектори професійної діяльності і невід’ємні від неї; а просвітницька діяльність у сфері мистецтва сама по собі постає як цінність. Таким чином:

1) ціннісна сфера музиканта-педагога має двоєдину спрямованість: на саморозвиток, передусім, у мистецтві, і на готовність впливати на формування мистецьких цінностей інших людей. Отже, студент-музикант, залучаючись до просвітницької діяльності стосовно інших, неминуче перетворюється на суб'єкта саморозвитку в ній. Саме ця вхідна позиція визначає вектори методичного пошуку (наступна вихідна позиція);

2) методика залучення до просвітницької діяльності студентів-музикантів як професійно значимої має переслідувати ці дві изілі одночасно: 
- оволодіння способами просвітництва невід 'ємно від самопросвітництва;

- розширення поля поліхудожнього пізнання (також з двох позицій):

а) у сфері музики, що перебуває в центрі підготовки і самопідготовки;

б) у сфері інших видів мистецтва, пріоритетно центрованих на музиці.

Означені позиції постають як змістове підгрунтя для визначення необхідних педагогічних умов для якнайповнішої реалізації ціннісного потенціалу мистецького просвітництва.

Першою педагогічною умовою $\epsilon$ забезпечення такого залучення студентамузиканта до оволодіння професією педагога, яке 6 охоплювало виконавську, музикознавчу і методичну підготовку у взаємозв'язку та обов'язково в спрямуванні до передачі набутого досвіду і оволодіння для цього відповідними музикантськими і художньо-комунікативними уміннями. Передбачається, що мотивування до просвітництва має бути присутнє в кожному із зазначених складників - виконавській, музикознавчій, методичній підготовці. Дотримання цієї умови визначає методичні пошуки в бік визначення групи методів, що стосуються пробудження $і$ поглиблення мотивації до комплексу музичної діяльності - до музикантського зростання як різнобічного та в ланцюгу «аналіз та інтерпретація творів у процесі сприймання музикознавче осмислення творів та історико-стильових процесів - виконавська інтерпретація музичних творів - художня комунікація».

Друга педагогічна умова - забезпечення у змісті та безпосередній організації фахової підготовки обов'язкового поліхудожнього розвитку, який також присутній в усіх означених складниках діяльності - виконавському, музикознавчому, методичному та спрямований як на самовдосконалення, так і на передачу вже зазначеного досвіду. Дотримання цієї умови подібно до першої: спрямовує методичні пошуки в бік визначення групи методів, що стосуються мотиваџійного занурення в різні види мистецтвва (сприймання та аналізу), котре до того ж охоплює оволодіння понятійним тезаурусом у сфері різних видів мистецтва, передусім для організації та здійснення художньої комунікації із іншими суб'єктами просвітництва.

Як бачимо, обидві педагогічні умови потребують специфічних методів, але зі спільним «ядром» - мотивуванням та здійсненням художньої комунікації, ще точніше мотивування до набуття таких умінь, які 6 уможливили ефективну художню 
комунікацію. Крім того, об’єднувальним особистісним механізмом підготовки студентамузиканта в контексті зазначеної в статті проблеми є суб'єктність у створенні відповідного освітнього середовища, яке постає одночасно музично-освітнім, поліхудожньо-освітнім із центром «музика», діалогічним, що й забезпечує художню комунікацію - як комунікацію суб'єктів між собою і суб'єктів із творами мистецтва [2-4; $7 ; 14 ; 16 ; 17]$. У такий спосіб, сутність методики як раз і полягає в націленості різнобічної, зокрема поліхудожньої підготовки педагога-музиканта на вмотивоване оволодіння методами, формами, різноманітними прийомами та уміннями художньої комунікації як «ядром» просвітнищької діяльності.

Зауважимо, оскільки художня комунікація пронизує всі складники діяльності музиканта, остільки формування її здатності в майбутніх педагогів-музикантів потребує спільного педагогічного механізму просвітницької діяльності, яким виокремлюємо функціонування специфічного освітнього середовища як художньо-просвітнищького середовищча.

Таким чином, залучення студентів-музикантів до створення і функціонування такого середовища як його повноцінних суб'єктів може бути окреслено як стрижнева педагогічна умова формування художніх цінностей, що реалізується через дві інші окреслені вище педагогічні умови з відповідними методичними орієнтирами.

Висновки. Отже, у статті розглянуто взаємозв'язок педагогічних умов i методичних основ ефективного формування художніх цінностей майбутніх педагогівмузикантів невід'ємно від залучення їх до мистецько-просвітницької діяльності як професійної. Педагогічні умови, які вибудовані в ієрархію, мають забезпечуватися методикою, в центрі якої - художня комунікація. Попри те, що феномен художньої комунікації, як і освітнього середовища, широко вивчається психологами мистецтва, мистецтвознавцями й мистецькою педагогікою (О. Комаровська, Д. Леонтьєв, О. Рудницька та ін.), автором подано зв'язок означених дефініцій, де художня комунікація як складник професійної діяльності є стрижнем художньо-просвітницького середовища, в якому відбувається підготовка до цієї діяльності.

Крім того, перспектива дослідження визначається реаліями життя: виклики i ризики сучасних інформаційних потоків, що впливають на цінності людини, висувають особливі вимоги щодо комунікації у віртуальному просторі [13], через що потребується 
пошук специфічних методик іiі здійснення, зокрема тих, що врівноважують послаблені позиції комунікації міжособистісної, яка вкрай важлива для мистецької сфери, для формування художніх цінностей і має бути «олюдненою».

\section{References}

1. Bao Lan. Kulturno-prosvetytelskaia deiatelnost [Cultural and educational activities in the Chinese media]. St. Petersburg:Sankt-Peterburgskii gosudarstvennyi universitet, 2016. $121 \mathrm{p}$.

2. Komarovska O. A. Khudozhno-intonatsiinyi prostir zhyttia yak dzherelo tsinnostei pidrostaiuchoi osobystosti [Artistic and intonational space of life as a source of values of the growing personality]. Topical issues of education: Collective monograph. Lisbon: Pegasus Publishing, 2018. Pp. 260-280.

3. Komarovska O. A. Tsinnisnyi kontekst mystetskoi osvity [Value context of art education]. Topical issues of pedagogy: Collective monograph. Magic Editions, Rome, Italy, 2019. P.131-155.

4. Komarovska O. A. Mystetska podiievist osvitnoho seredovyshcha $v$ konteksti khudozhnikh tsinnostei osobystosti [Artistic events of the educational environment in the context of artistic values of the individual]. Theoretical and methodological problems of raising children and students. 2020. Vol. 24 (1). P. 252-270.

5. Leontiev D. A.Vnutrennii mir lichnosti [The inner world of the individual]. Psikholofiia lichnosti v trudakh otechestvennykh uchenykh.St. Petersburg, 2001. P. 372-377.

6. Modelnyi zakon o prosvetitelskoi deiatelnosti. Pryniat na dvadtsatom plenarnom zasedanyy Mezhparlamentskoi Assamblei gosudarstv-uchastnykov SNH [Model law on educational activities. Adopted at the twentieth plenary session of the Interparliamentary Assembly of the CIS member states (Resolution No. 20-15 of December 7, 2002) URL: https://zakon.rada.gov.ua/laws/show/997_a09\#Text

7. Pet'ko L. V. Formuvannya profesiyno orientovanogo inshomovnogo navchalnogo seredovishcha $v$ umovah universitetu dlya studentiv spetsialnosti «Muzichne mistetstvo» (na prikladi virsha Meri Hovitt «Pavuk $i$ Muha») [Formation of professionally oriented foreign language teaching environment in the terms of university for students of Music Art specialty (on illustration of a poem "The Spider and the Fly» by Mary Howitt)]. Naukovi zapiski Berdyanskogo derzhavnogo pedagogichnogo universitetu. Pedagogichni nauki: zb. nauk. pr. Issue 1. Berdyansk : FO-P Tkachuk O.V., 2016. P. 184-190.

8. Tatenko V. A. Problemy subekta v sovremennoi psikhologii (ukrainskaia shkola) [Problems of the subject in modern psychology (Ukrainian school)]. FilosofskopsikhologicheskoenasledieS. L. Rubinshteina; red. K.A. Abulkhanova, S.V. Tikhomirova. Moscow: Izd-vo «Institut psikhologii RAN», 2011. P. 371-387.

9. Rogers K. R.Vzghliad na psykhoterapyiu. Stanovlenye cheloveka[A look at psychotherapy. Becoming a human being]. Moscow: Progress, "Universe", 1994. 480 p.

10. Frankl V. Chelovek v poiskakh smysla [Man's search for meaning]. Moscow: Progress, 1990. 367 p. 
11. Chen Lyang. Khudozhno-tsinnisna sfera uchyteliv muzyky $v$ konteksti fakhovoi pidhotovky [Artistic and value sphere of music teachers in the context of professional training]. Molod i rynok. No. 3-4 (182-183). 2020. P.157-161. DOI: https://doi.org/10.24919/23084634.2020.216806

12. Chen Lyang. Tsinnisnyi potentsial mystetsko-prosvitnytskoi diialnosti maibutnikh uchyteliv muzyky[Value potential of artistic and educational activities of future music teachers]. Estetyka $i$ etyka pedahohichnoi dii: zb. nauk. pr. / In-t ped. osvity i osvity doroslykh imeni Ivana Ziaziuna NAPN Ukrainy, Poltav. nats. ped. un-t imeni V. H. Korolenka. 2021. Vol. 23 (2). P. 70-79.

13. Holinska T., Komarovska O., Melnyk O., Petko L., Shpitsa R., Sova O., Strohal T. Cloud Technologies in Art Entrepreneurship Education. Journal of Entrepreneurship Education (JEI). USA. 2019. Vol. 22, Issue: 5. P. 1-6.

14. Kanishevska, L., Matviienko, O., Pankiv, L., Pet'ko, L., Stepanova, L., Ragozina, V., Soichuk, R. (2020). Innovations in arts and cultural education: entrepreneurial aspect. Journal of Entrepreneurship Education, 23(1).

15. Kozii O., Ulianova V., Bilostotska O., Kachmar O., Bakhmat N., Prokopchuk V. \& Komarovska O. Experience in Developing Imaginative and Intonational Competencies in Future Music Teachers. Revista Romaneasca pentru Educatie Multidimensionala. 2020. Vol. 12 (4). P. 16-37 DOI: https://doi.org/10.18662/rrem/12.4

16. Pet'ko L.V. Brainstorming and the formation of professionally oriented foreign language teaching environment in the conditions of university (for the specialties 023 «Fine Arts» and 022 «Design») // Economics, management, law: challenges and prospects: Collection of scientific articles. Psychology. Pedagogy and Education. - Discovery Publishing House Pvt. Ltd., New Delhi, India. 2016. P. 214-217.

17. Pet'ko Lyudmila. Sociocultural comprehension of ethnoconcept "RED RUE" // Science and society: Collection of scientific articles. Edizioni Magi, Roma, Italia, 2017. P. 460-466.

18. The Culture of China. Understanding China / ed. by K. Kuiper. New York: Britannica Educational Publishing, 2010. 300 p.

19. Xia Gaoyang,\& Komarovska O. A.Polyartistic potential of Music theory subjects in training music teachers. Intellectual Archive.Toronto: Shiny Word.Corp. (Canada). 2018. (November/December). Vol. 7. No. 6. P. 82-89.DOI: https://doi.org/10.32370/2018_11_10

\section{Translation of the Title, Abstract and References to the Author's Language}

УДК 378.37.01:78

Чень Лян. Методичні засади формування художніх цінностей студентівмузикантів у мистецько-просвітницькій діяльності. Стаття присвячена проблемі ціннісного становлення стулента-музиканта як майбутнього вчителя музики в процесі професійної підготовки. Мистецьке-просвітнцтво розглядається як складник такої підготовки, що акумулює виконавський, музикозначий, методичний напрями. Мистецьке просвітнцтво вчителя музики зумовлює поліхудожній вектор професійної підготовки, який містить пізнання музичного та інших видів мистецтва. Успішність мистецького просвітництва забезпечується суб'єктністю майбутнього педагога- 
музиканта, який приймає таку діяльність як універсальну професійну цінність. Обгрунтовується ієрархія педагогічних умов ефективної мистецько-просвітницької діяльності. Викладено вихідні позиції для обгрунтування методичних основ мистецького просвітництва майбутнього вчителя музики, а саме: іiі спрямованість на саморозвиток i на цінності інших людей. Групи методів стосуються мотивування до комплксу музичної діяльності, поліхудожнього розвитку, тезаурусу у сфері різних мистецтв. Ядром методичних засад є художня комунікація суб'єктів із мистецтвом та міжособистісна. Для забезпечення художньої комунікації огрунтовується необхідність функціонування специфічного художньо-просвітнцького середовища. Пояснюється функціональний зв'язок педагогічних умов i методів формування художніх цінностей студентівмузикантів у мистецько-просвітницькій діяльності як суб'єктів художнопросвітницького середовища. Визначаються перспективи дослідження проблеми, зумовлені актуалізацією процесів віртуального спілкування, ризиками нівелювання міжособистісної художньої комунікації.

Ключові слова: студенти-музиканти, мистецько-просвітницькка діяльність, художні цінності, художня комунікація, художньо-просвітнцьке середовище.

\section{Лimepamypa}

1. Бао Лань. Культурно-просветительская деятельность в СМИ Китая. СПб, СанктПетербургский государственный университет. 2016. 121 c. URL: https://nauchkor.ru/uploads/documents/587d368d5f1be77c40d59232.pdf

2. Комаровська, О. А. Художньо-інтонаційний простір життя як джерело цінностей підростаючої особистості / Topical issues of education: Collective monograph. Lisbon: Pegasus Publishing. 2018. C. 260-280.

3. Комаровська О. А. Ціннісний контекст мистецької освіти / Topical issues of pedagogy: Collective monograph. Edizioni Magi, Roma, Italia, 2019. P. 131-155.

4. Комаровська О. А. Мистецька подієвість освітнього середовища в контексті художніх цінностей особистості. Теоретико-методичні проблеми виховання дітей та учнівської молоді. 2020. Вип. 24. Кн. 1. С. 252-270.

5. Леонтьев Д.А. Внутренний мир личности. Психология личности в трудах отечественных ученых. Санкт-Петербург, 2001. С. 372-377.

6. Модельный закон о просветительской деятельности. Принят на двадцатом пленарном заседании Межпарламентской Ассамблеи государств-участников СНГ (Постановление N 20-15 от 7 декабря 2002 г.)

https://zakon.rada.gov.ua/laws/show/997_a09\#Text

7. Петько Л.В. Формування професійно орієнтованого іншомовного навчального середовища в умовах університету для студентів спеціальності «Музичне мистецтво» (на прикладі вірша Мері Ховітт «Павук і Муха»). Наукові записки Бердянського державного педагогічного університету. Педагогічні науки: зб. наук. пр. Вип. 1. Бердянськ : ФО-П Ткачук О.В., 2016. С. 184-190.

8. Татенко В. А. Проблемы субъекта в современной психологии (Украинская школа). Философско-психологическое наследие С.Л. Рубинштейна / Под ред. К.А. Абульхановой, С.В. Тихомировой. - М.: Изд-во «Институт психологии РАН», 2011. С. 371-387. 
9. Роджерс К. Р. Взгляд на психотерапию. Становление человека : пер. с англ. / общ. ред. и предисл. Е. И. Исениной. Москва : Прогресс, «Универс», 1994. 480 с.

10. Франкл В. Человек в поисках смысла. Перевод с англ. и нем. Вступ ст. Д.А. Леонтьева. Москва: Прогресс, 1990. 367 с.

11. Чень Лян. Художньо-ціннісна сфера учителів музики в контексті фахової підготовки. Молодь $i$ ринокю № 3-4 (182-183), 2020. C. 157-161. DOI: https://doi.org/10.24919/2308-4634.2020.216806

12. Чень Лян. Ціннісний потенціал мистецько-просвітницької діяльності майбутніх учителів музики. Естетика і етика педагогічної дї: зб. наук. пр. / Ін-т пед. освіти і освіти дорослих імені Івана Зязюна НАПН України, Полтав. нац. пед. ун-т імені В. Г. Короленка. 2021. Вип. 23. С. 70-79.

13. Holinska T., Komarovska O., Melnyk O., Petko L., Shpitsa R., Sova O., Strohal T. (2019). Cloud Technologies in Art Entrepreneurship Education. Journal of Entrepreneurship Education (JEI). USA. Vol. 22, Issue 5, pp. 1-6.

14. Kanishevska, L., Matviienko, O., Pankiv, L., Pet'ko, L., Stepanova, L., Ragozina, V., Soichuk, R. (2020). Innovations in arts and cultural education: entrepreneurial aspect. Journal of Entrepreneurship Education, 23(1).

15. Kozii, O., Ulianova,V., Bilostotska, O., Kachmar,O., Bakhmat, N., Prokopchuk, V., \& Komarovska, O. (2020). Experience in Developing Imaginative and Intonational Competencies in Future Music Teachers. Revista Romaneasca pentru Educatie Multidimensionala, 12 (4), pp. 16-37. DOI: https://doi.org/10.18662/rrem/12.4

16. Pet'ko L.V. Brainstorming and the formation of professionally oriented foreign language teaching environment in the conditions of university (for the specialties 023 «Fine Arts» and 022 «Design») // Economics, management, law: challenges and prospects: Collection of scientific articles. Psychology. Pedagogy and Education. - Discovery Publishing House Pvt. Ltd., New Delhi, India. 2016. P. 214-217

17. Pet'ko Lyudmila. Sociocultural comprehension of ethnoconcept "RED RUE" // Science and society: Collection of scientific articles. - Edizioni Magi, Roma, Italia, 2017. P. 460-466.

18. The Culture of China. Understanding China / ed. by Kathleen Kuiper. New York : Britannica Educational Publishing, 2010. 300 p.

19. Xia Gaoyang. Polyartistic potential of Music theory subjects in training Music teachers / Xia Gaoyang, Komarovska Oksana. Intellectual Archive. Toronto: Shiny Word.Corp. (Canada). 2018. (November/December). Vol.7. No.6. PP. 82•89. DOI: https://doi.org/10.32370/2018_11_10 